\title{
HUBUNGAN PENGETAHUAN DAN PERILAKU PENCEGAHAN KEPUTIHAN PADA REMAJA KARANG TARUNA DI KABUPATEN CILACAP
}

\author{
Dewi Elliana ${ }^{1}$, Sri Mularsih ${ }^{2}$ \\ 1,2Akademi Kebidanan Abdi Husada Semarang
}

\begin{abstract}
One of the symptoms and signs of disease in female reproductive organs is vaginal discharge. Wrong personal hygiene behavior can cause itching in the vulva, vaginal discharge to an unpleasant odor in the female area. Teenagers are indeed a large group, vulnerable and at risk of reproductive health problems. The purpose of this study was to analyze the relationship between knowledge about personal hygiene with the behavior of preventing whiteness vaginal discharge in young women in Karang Taruna RW 2, Hamlet Village, Cipari District, Cilacap Regency. This study used a cross sectional design. The population is teenage girls aged 1618 years as many as 30 people. The study use total sampling technique. Result of this study was most respondents were 16 years old (57.1\%), Most of the personal hygiene knowledge is sufficient 11 respondents (36.7\%), most of the positive behavior of young women in preventing vaginal discharge is 29 respondents (96,7\%). There is a significant relationship between the knowledge of personal hygiene with the behavior of prevention of whiteness vaginal discharge ( $p$ value 0.01). It means there is a relationship between the two variables. Suggestions in this study is the female teenagers is expected to increase the provision of information on personal hygiene and vaginal discharge prevention for young women and the community.
\end{abstract}

Keywords : Vaginal Discharge; Prevention; Personal Hygiene 


\section{PENDAHULUAN}

Kesehatan reproduksi menurut World Health Organization (WHO) adalah kesejahteraan fisik, mental dan sosial yang utuh dan tidak hanya adanya penyakit atau kelemahan, dalam segala hal yang berhubungan dengan system reproduksi dan fungsi-fungsinya serta prosesprosesnya. Remaja didefinisikan sebagai masa peralihan dari masa kanak-kanak ke masa remaja. WHO dan Badan Kependudukan dan Keluarga Berencana Nasional (BKKBN) menyebutkan bahwa batas usia remaja adalah 12 sampai 24 tahun, sedangkan menurut Departemen Kesehatan Republik Indonesia antara 10 sampai 19 tahun dan belum kawin. (WHO, 2010).

Remaja atau adolescence berasal dari bahasa "adolescere" yang berarti "tumbuh" atau "tumbuh menjadi dewasa". Istilah adolescene yang berasal dari bahasa inggris, saat ini mempunyai arti yang cukup luas mencangkup kematangan mental, emosional, sosial, dan fisik (Proverawati, 2009).

Menurut Piaget, masa remaja adalah usia dimana individu mulai berintegrasi dengan masyarakat dewasa. Individu tidak lagi merasa di bawah tingkatan orang yang lebih tua melainkan berada dalam tingkatan masa transisi yang ditandai oleh adanya perubahan fisik, emosi, dan psikis. Masa remaja umumnya berumur 16-19 tahun dan merupakan masa peralihan menuju dewasa (Proverawati, 2009).

Jumlah remaja saat ini sangat besar sehingga dapat mempengaruhi kelangsungan hidup di dunia. PBB memperkirakan jumlah remaja di dunia mencapai hampir separuh populasi dunia. (Narendra,2002). Menurut data statistik jumlah penduduk di Jawa Tengah pada tahun 2011 mencapai 12348985 jiwa, tercatat jumlah remaja usia 10-19 tahun adalah 5.842.389 (17,90\%) dengan jumlah remaja putri 2.794 .412 jiwa $(47,82 \%)$ dari jumlah remaja keseluruhan. Di Kota Cilacap, tercatat jumlah remaja usia 10-19 tahun berjumlah 234.095 jiwa.Di Karang Taruna di Dukuh sawah jumlah remaja putri sebanyak 30 jiwa. Di Karang Taruna di Dukuh sawah jumlah remaja putri sebanyak 30 jiwa (BPS, Provinsi Jawa Tengah, 2011) Remaja putri rata-rata memasuki usia menarche pada usia 13 sampai 15 tahun dan kebanyakan remaja putri juga belum memperoleh informasi atau pengetahuan banyak mengenai personal hygiene. Pemberian pengetahuan dan informasi tentang kesehatan reproduksi perlu diberikan pada usia dini, karena pada usia tersebut kematangan organ reproduksi mulai berfungsi (Aulia, 2009). Remaja memang kelompok yang besar jumlahnya, rentan dan mempunyai resiko gangguan kesehatan reproduksi. Pada saat menstruasi para remaja putri tersebut juga sering melakukan kesalahan berupa penanganan yang tidak benar personal hygiene terhadap genetalianya. Hal ini 
dapat disebabkan karena pengetahuan dan informasi yang remaja putri peroleh sangat sedikit sehingga sikap dan praktek. personal hygiene sering salah hal ini dapat menyebabkan gatal-gatal pada vulva, keputihan sampai bau yang tidak sedap di daerah kewanitaan. Salah satu gejala dan tanda-tanda penyakit infeksi organ reproduksi wanita adalah terjadinya keputihan. Keputihan( Flour albus ) adalah cairan berlebihan yang keluar dari vagina (Nugroho, 2010).

Meskipun termasuk penyakit yang sederhana, kenyataanya keputihan adalah penyakit yang tidak mudah disembuhkan. Dengan demikian, perawatan organ reproduksi genetalia merupakan salah satu komponen hygiene individu, yang juga memegang peran penting dalam menentukan status kesehatan. Dalam hal ini adalah terhindarnya individu tersebut dari infeksi sehingga perilaku yang mendasar seperti misalnya cara mencuci organ reproduksi, ganti pembalut rutin hal ini di karenakan permukaan pembalut yang bersentuhan dengan kulit vagina akan membuat vagina menjadi lembab. Pembalut yang lembab dan dipakai terlalu lama akan menimbulkan penyakit akibat jamur dan bakteri.

Pengetahuan merupakan hasil "tahu" dan ini terjadi setelah orang mengadakan pengindraan terhadap suatu objek tertentu. Pengindraan terhadap obyek terjadi melalui panca indra manusia yakni penglihatan, pendengaran, penciuman, rasa dan raba dengan sendiri. Pada waktu pengindraan sampai menghasilkan pengetahuan tersebut sangat dipengaruhi oleh intensitas perhatian persepsi terhadap obyek. Sebagian besar pengetahuan manusia diperoleh melalui mata dan telinga. (Notoatmodjo, 2003).

Dari wawancara di bidan menyatakan ada remaja putri yang pernah datang ke tempatnya dengan keluhan mengeluarkan cairan pada alat genetalia dan merasa gatal sehingga menyebabkan kemerahan pada daerah genetalia, remaja tersebut adalah salah satu remaja dari Karang Taruna Dukuh Sawah.

Dari latar belakang di atas maka peneliti tertarik untuk melakukan penelitian tentang "Hubungan Pengetahuan Personal Hygiene Remaja Putri Dengan Perilaku Mencegah Keputihan di Karang Taruna Dukuh sawah Kabupaten Cilacap.

\section{METODOLOGI PENELITIAN}

Populasi pada penelitian ini yaitu remaja putri umur 16-18 tahun di Karang Taruna RW 2 Desa Dukuh sawah Kecamatan Cipari Kabupaten Cilacap. Jumlah populasinya adalah 30 remaja. Teknik sampling pada penelitian ini menggunakan teknik total sampling pada keseluruhan populasi, sehingga didapatkan 30 sampel. Istilah lainnya sampling jenuh adalah sensus, dengan semua anggota populasi dijadikan sampel

Untuk menganalis hubungan antara 2 variable yaitu variable independen dan variable dependen. Hubungan tingkat 
pengetahuan dengan perilaku pencegahan keputihan digunakan chi square / fisher exact.

\section{HASIL PENELITIAN DAN BAHASAN}

\section{A. Hasil Penelitian}

Di bawah ini merupakan analisa univariat dari responden penelitian berdasarkan tingkat pengetahuan.

Tabel 1. Distribusi frekuensi responden berdasarkan tingkat pengetahuan tentang personal hygiene

\begin{tabular}{llcc}
\hline \multirow{2}{*}{ No } & Tingkat Pengetahuan & \multicolumn{2}{c}{ Frekuensi } \\
\cline { 3 - 4 } & personal hygiene & $\mathrm{N}$ & $\%$ \\
\hline 1 & Baik & 10 & 33,3 \\
\hline 2 & Cukup & 11 & 36,7 \\
\hline 3 & Kurang & 9 & 30,0 \\
\hline & Jumlah & 30 & 100 \\
\hline
\end{tabular}

Dari tabel 1 diatas, menunjukkan bahwa pengetahuan tentang personal hygiene sebagian besar cukup sebanyak 11 $(36,7 \%)$.

Tabel. 2 Distribusi frekuensi responden berdasarkan perilaku dalam mencegah keputihan

\begin{tabular}{lll}
\hline $\begin{array}{l}\text { Perilaku dalam } \\
\text { Mencegah } \\
\text { Keputihan }\end{array}$ & $\begin{array}{c}\text { Frekuensi } \\
(\mathrm{n})\end{array}$ & $\begin{array}{c}\text { Prosentase } \\
\%\end{array}$ \\
\hline Positif & 29 & 96,7 \\
\hline Negatif & 1 & 3,3 \\
\hline Total & 30 & 100,0 \\
\hline
\end{tabular}

Dari tabel 2 diatas, menunjukkan bahwa perilaku dalam mencegah keputihan sebagian besar positif sebanyak 29 (96,7\%) responden. Responden yang perilaku negatif dalam mencegah keputihan 3,3\%.

Di bawah ini merupakan tabel silang antara pengetahuan personal Hygiene dengan perilaku pencegahan keputihan pada responden.
Tabel 3 Hubungan Pengetahuan Personal Hygiene dengan Perilaku Pencegahan Keputihan

\begin{tabular}{lllllll}
\hline \multirow{2}{*}{ Pengetahuan } & \multicolumn{9}{l}{ Perilaku mencegah } \\
\cline { 2 - 7 } & \multicolumn{2}{l}{ positif } & \multicolumn{2}{l}{ Negatif } & \multicolumn{2}{l}{ Jumlah } \\
\cline { 2 - 7 } & $\mathrm{N}$ & $\%$ & $\mathrm{~N}$ & $\%$ & $\mathrm{~N}$ & $\%$ \\
\hline Kurang & 8 & 26,7 & 1 & 3,3 & 9 & 30.0 \\
\hline Cukup & 11 & 36,7 & 0 & 0 & 11 & 36,7 \\
\hline Baik & 10 & 33,3 & 0 & 0 & 10 & 33,3 \\
\hline Total & 29 & 96,7 & 1 & 3,3 & 30 & 100 \\
\hline$X^{2}=9,04$ & & & & & & \\
p value: 0,01 & & & & & &
\end{tabular}

Berdasarkan tabel 3 hasil penelitian menunjukkan bahwa dari 30 responden menunjukan bahwa responden yang berperilaku mencegah keputihan yang positif dan memiliki pengetahuan personal hygiene cukup $(36,7 \%)$ lebih besar dari responden yang berpengetahuan baik $(33,3 \%)$ serta responden yang berperilaku pencegahan keputihan yang negatif dan pengetahuan tentang personal hygiene yang cukup dan baik $(0,0 \%)$ lebih kecil dari responden yang berpengetahuan personal hygiene kurang $(3,3 \%)$.

\section{B. Pembahasan}

Menurut Wawan dan Dewi (2010) faktor-faktor yang dapat mempengaruhi pengetahuan adalah faktor pendidikan, pekerjaan, umur, lingkungan, dan sosial budaya. Responden dalam penelitian ini sudah sering mendapatkan pendidikan tentang kesehatan reproduksi namun baru mendapatkan pendidikan kesehatan tentang personal hygiene pada remaja. Hal ini juga disebabkan oleh informasi yang responden terima tidak lengkap atau tidak menyeluruh. Informasi juga memberikan pengaruh terhadap pengetahuan 
seseorang.meskipun orang tersebut memiliki pendidikan yang rendah, tapi jika mendapatkan informasi yang baik dari media masa seperti televisi, radio, atau surat kabar maka hal tersebut akan meningkatkan pengetahuan seseorang. remaja putri perlu mendapatkan pengetahuan personal hygiene misalnya melalui pendidikan kesehatan di sekolah, media massa, atau melalui konseling di fasilitas kesehatan.

Kebanyakan responden belum memiliki pengetahuan tentang personal hygiene dan pencegahan keputihan. Pengetahuan yang belum baik ini dapat dipengaruhi oleh umur. Umur responden adalah 15-20 tahun, dimana usia tersebut merupakan usia yang belum cukup matang dan belum memiliki banyak pengalaman.

Usia yang cukup matang dapat membuat seseorang lebih baik dalam menanggapi suatu objek atau masalah. Bertambahnya umur seseorang dapat berpengaruh pada pengetahuan yang diperolehnya, akan tetapi pada umur-umur tententu atau menjelang usia lanjut kemampuan penerimaan atau mengingat suatu pengetahuan akan berkurang. Pengalaman merupakan sumber suatu pengetahuan atau pengalaman itu merupakan suatu cara untuk memeperoleh kebenaran pengetahuan. Pengalaman pribadi dapat digunakan sebagai suatu upaya untuk memperoleh suatu pengetahuan, seseorang yang lebih dewasa dipercaya dari orang belum tinggi kedewasaannya. Hal ini sebagai pengalaman dan kematangan jiwa.

Hasil penelitian menunjukkan bahwa sebagian besar remaja putri memiliki perilaku positif dalam pencegahan keputihan yaitu sebanyak 29 (96,7\%) dan yang memiliki perilaku negatif sebanyak 1 responden $(3,3 \%)$.

Menurut Soebroto (2009), perilaku untuk mencegah keputihan pada remaja putri adalah dengan menjaga kebersihan pada alat genitalia remaja putri di Karang Taruna di Desa Dukuh Sawah Kota Cilacap menjaga personal hygiene karena sebagian mereka sudah mengetahui tentang manfaat menjaga personal hygiene, sehingga perilaku sebagian mereka untuk mencegah keputihan sebagian besar positif. Menurut Notoatmodjo (2010) faktor-faktor yang mempengaruhi perilaku individu dalam pemeliharaan dan peningkatan kesehatan dipengaruhi oleh beberapa faktor yaitu pengetahuan, sikap masyarakat, tingkat pendidikan, tingkat ekonomi sosial, sarana dan prasarana atau fasilitas kesehatan, jarak, lokasi, biaya, sumber daya, dan perilaku tokoh masyarakat, tokoh agama, termasuk petugas kesehatan.

Responden sebagian besar memiliki perilaku positif dalam pencegahan keputihan karena pengetahuan responden tentang keputihan sebagian besar mengetahui cukup. Dari keseluruhan responden yaitu sebanyak 28 responden $(86,9 \%)$ memiliki perilaku positif . Respon yang memiliki perilaku negatif sebanyak 2 responden $(3,1 \%)$ karena sebagian 
responden sudah mengetahui sehingga perilaku pencegahan keputihan lebih besar positif.

Berdasarakan hasil tabel silang, responden yang memiliki Pengetahuan tentang personal hygiene cukup cenderung memiliki perilaku positif dalam pencegahan keputihan. Responden yang memiliki pengetahuan tentang personal hygiene kurang cenderung memiliki perilaku negatif dalam pencegahan Keputihan.

Hal ini menunjukan ketidakcenderungan pengetahuan remaja putri tentang personal hygiene berhubungan dengan perilaku pencegahan keputihan. Analisis dengan uji chi square diperoleh hasil $p$ value 0,01 yang berarti kurang dari 0,05 sehingga menunjukkan ada hubungan pengetahuan personal hygiene dengan perilaku pencegahan keputihan di Karang Taruna Remaja Desa Dukuh Sawah Kota Cilacap.

\section{KESIMPULAN}

1. Sebagian besar pengetahuan remaja putri tentang personal hygiene cukup yaitu 11 responden $(36,7 \%)$

2. Sebagian besar perilakunya positif pada penecegahan keputihan yaitu 29 responden $(96 \%, 7)$

3. Ada hubungan antara pengetahuan personal hygiene dengan perilaku pencegahan keputihan

\section{DAFTAR PUSTAKA}

1. Arikunto, Suharsimi.2006. Prosedur Penelitian Suatu Pendekatan Praktik. Rineka Cipta. Jakarta.

2. Atmaningtyas, Naila. 2009. Cantika dan Sehat Payudara. Getar Hati.

3. Azwar, Saifuddin. 2012. Metode Penelitian. Pustaka Pelajar. Yogyakarta.

4. Bustan, M.N. 2007. Epidemiologi Penyakit Tidak Menular. Rineka Cipta, Jakarta.

5. Cahyaningsih, Dwi Sulistyo. 2011. Pertumbuhan Perkembangan Anak dan Remaja. CV Trans Info Media, Jakarta.

6. Dinkes.2012. Profil Kesehatan Jawa Tengah. Dinkes, Jawa Tengah.

7. Ghofar, Abdul.2009. Cara Mudah Mengeal \& Mengobati Kanker. Flamingo.Yogyakarta.

8. Hidayat, Aziz Alimul. 2010. Metode Penelitian Kebidanan Teknik Analisis Data.Salemba Medika, Jakarta.

9. Nisman, Wenny Artanty. 2011. Lima Menit Kenali Payudara Anda. CV Andi Offset, Yogyakarta.

10. Notoatmodjo, Soekidjo. 2007. Promosi Kesehatan dan IImu Perilaku. Rineka Cipta, Jakarta.

11. Notoatmodjo. 2010. Metode Penelitian Kesehatan. Rineka Cipta, Jakarta.

12. Notoatmojo. 2010. IImu Perilaku Kesehatan. Rineka Cipta, Jakarta.

13. Septiani, Sari dan Mahyar Suara. 2013. Faktor-faktor Yang Berhubungan Dengan Perilaku Pemeriksaan Payudara Sendiri (Sadari).Jurnal Kesehatan IImiah.

14. Sulistyaningsih. 2011. Metode Penelitian Kebidanan : Kuantitatif Kualitatif.Gerah IImu, Yogyakarta.

15. Suryaningsih, Endang Koni \& Bertiani Eka Sukaca. 2009. Kupas Tuntas Kanker Payudara. Paradigma Indonesia, Yogyakarta

16. Wawan, A \& Dewi, M. 2011. Pengetahuan, Sikap, dan Perilaku Manusia. Nuha Medika, Yogyakarta 